\title{
Managing Training for Civil Servants with Planning Roles in Indonesia: Lessons from Singapore
}

\author{
Feita Puspita Murti ${ }^{1}$ \\ Ministry of National Development Planning/Bappenas - Indonesia
}

\begin{abstract}
Indonesia is a developing country that is vigorously seeking to boost its economic growth. One of the nine programs to encourage national development is to improve the quality of civil servants, to strengthen the capacity for policy design and implementation in ministries and institutions, and hence to improve public service delivery. Some researchers argue that many developing countries have attempted to strengthen civil service training, but only a few have succeeded in making significant contributions to improving their institutions. A group of researchers has identified ten factors that they regard as critical for training management effectiveness, which has applied in the Singapore civil service training institutions. The researchers suggest that the same elements may be necessary for developing countries. This study attempts to evaluate the potential application of the ten critical factors affecting training management effectiveness for Indonesian civil service training institutions. This thesis presents a comparative analysis of training management in Indonesia and Singapore. In this 'lens' of comparison, the Singapore model is used as a framework to understand the training management model in Indonesia. Based on the findings, nine out of ten factors could be implemented in the Indonesian model. However, factors related to the political context are likely to be challenging, as the political environment in the developed and developing countries are somewhat different.
\end{abstract}

Keywords: training, training institution, management, civil servant, planning roles, developing country

\footnotetext{
${ }^{1}$ Feita Puspita Murti is a staff at Center for Educational Planning and Training Planners, Ministry of National Development Planning/Bappenas RI. E-mail: feitapuspitamurti@gmail.com
} 


\title{
Managing Training for Civil Servants with Planning Roles in Indonesia: Lessons from Singapore
}

\author{
Feita Puspita Murti
}

\section{Introduction}

Indonesia is a developing country that is seeking to boost its economic growth vigorously. In the last five years, funds from the state budget have allocated for priority missions called 'Nawacita,' a nine-point development program introduced by President Jokowi. One of the tasks is to improve the quality of life through education. Twenty percent of the state budget allocated for education, of which some funds distributed for the government's training departments. The purpose of training programs for civil servants is to strengthen the capacity in ministries and institutions, and hence to improve public service delivery. One of the most crucial training departments is the Centre for Planners' Education and Training (CPDET) in the Ministry of National Development Planning. The CPDET has designed to organize training and education for officials in central and regional governments who have a role as planners. Planners considered as the critical strategic thinkers in the Indonesian Government.

Every year, CPDET targets more than 500 civil servants with planning roles from central and local governments to attend various training (degree and non-degree) programs. This number aimed to increase up to 70 percent each year (CPDET, 2013). From 2005 until 2018, 45,472 planner civil servants participated in a training program conducted by the CPDET. Significant numbers attended training programs; however, what is critical is how they are trained and to what extent they contribute to their organizations. Many training institutions in developing countries have criticized as most of them did not improve the capacity of training participants to provide to their organizations (Tessema et al., 2007). Tessema et al. (2007) investigate how Singapore has successfully managed training for its civil service institutions. They suggest that developing countries can learn from Singapore by implementing 'ten critical factors affecting civil service institution' (Kerrigan \& Luke, 1987; Kubr \& Prokopenko, 1989; Lynton \& Pareek, 2011; Thomas \& Mellon, 1995; Wanassinghe, 1988):

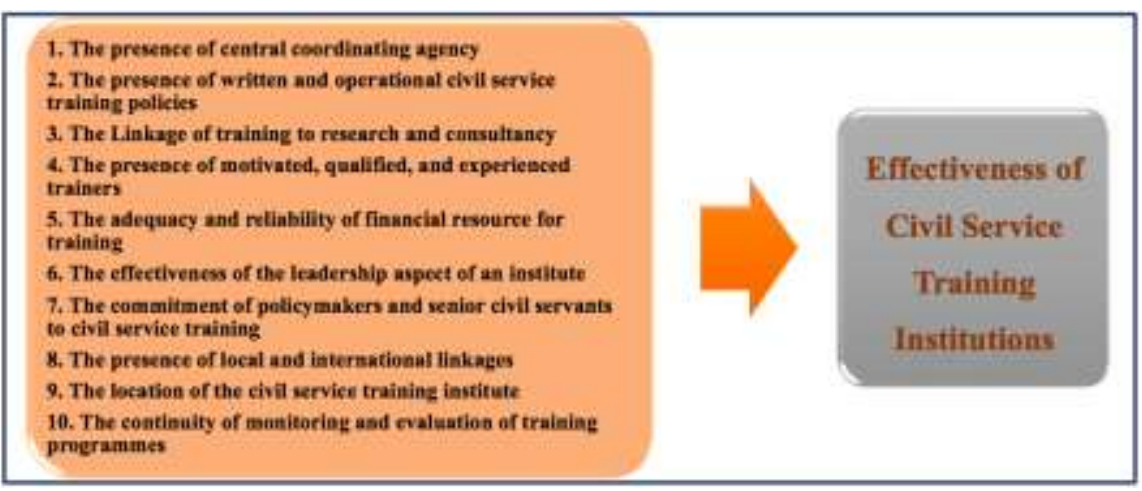

Figure 1. Factors Affecting Civil Service Training Institution

\subsection{Research Problem and Research Methodology}

This thesis aims to examine whether the implementation of the ten critical factors affecting civil service institution in Singapore suggested by Tessema and colleagues, may improve management efficacy in the CPDET. The primary research question of this thesis is: Is the Singapore civil service training model a good model for Indonesia? 
The questions will be examined through reflection upon the CPDET experience in managing training for Indonesian Civil Servants. This thesis presents a comparative analysis of the training management model in Indonesia and Singapore. In this 'lens' of comparison, this study will use the Singapore model as a framework to understand the training management model in Indonesia. The research involves evaluating whether Indonesia's training management model is consistent with the ten critical factors identified in the Singapore model.

The evaluation was done using a variety of data and other information obtained from secondary sources. The thesis is mainly based on the archival documents which have been gathered from:

- the CPDET: i.e., standard operating procedures, training policies, financial records, and cooperation agreements with a domestic and international organization

- consultants: i.e., monthly or yearly report, project completion reports

- training providers; i.e., training evaluation

The approach taken in this study is, therefore, primarily qualitative rather than quantitative. However, some previous quantitative-type analysis by consultants regarding the contributions by training alumni to their organizations will be reviewed.

\subsection{Limits on the scope of this Study}

The study discusses the implementation of the ten critical factors affecting training civil service management. Despite hundreds of training departments for civil servants in Indonesia, the thesis will focus on CPDET training management. First, the CPDET is central for planner's development that formulates policies for the planner, which has a strong influence on central and local government. Secondly, CPDET is a department under a central government office, and hence training-related documents needed for this study are relatively accessible.

\subsection{Significance of The Study}

The result of the study will be of great benefit to the following:

\section{a. The Policymaker (Minister of National Development Planning)}

Findings from this study regarding factors affecting the quality of training management should be valuable for the Minister to make evidence-based training policy.

\section{b. The Head CPDET}

Findings from the thesis will provide the Head of CPDET with information and analyses regarding factors affecting training management in the organization. These factors will reveal the strengths and weaknesses of the organization and help the leader to plan the advancement of training management.

\section{c. Training Providers}

Finding of the study will help universities, as training providers, to evaluate the quality of trainers, facilities, and teacher competency about training delivery.

\section{Theoretical Framework}

This chapter provides a conceptual framework to underpin the research study. This study based on two foundation theories: the strategic elements in an organization and the ten critical factors are affecting these elements in managing training institutions proposed by Tessema et al. (2007). The vital components will be described using the 'Strategic Triangle' developed by Moore in 1995. 
Training departments are the organizations or units under a government that manage training programs for civil servants. Training departments have a direct relationship with the government. Training institutes or training providers are the units where the government holds and implements training programs or courses, such as schools, colleges, and universities. Training institutes have an indirect relationship with the government. The training department facilitates the relationship between government and training institutions.

\subsection{Strategic Triangle}

In 1995 Mark H. Moore developed an organizational strategy for for-profit, not-forprofit, and governmental organizations to create value and achieve their objectives. While for-profit organizations have succeeded in developing an approach that focuses on customers, competition, and market, however, not-for-profit and governmental organizations should develop an alternative strategy as they are more social-oriented rather than revenue-oriented (Moore, 2000). Moore (1995) and Heyman (1987) developed the idea that plan for public sector organizations should consist of three crucial elements: 'public value to be created, source of legitimacy and support, and operational capacity to deliver public value' (Figure 2 ).

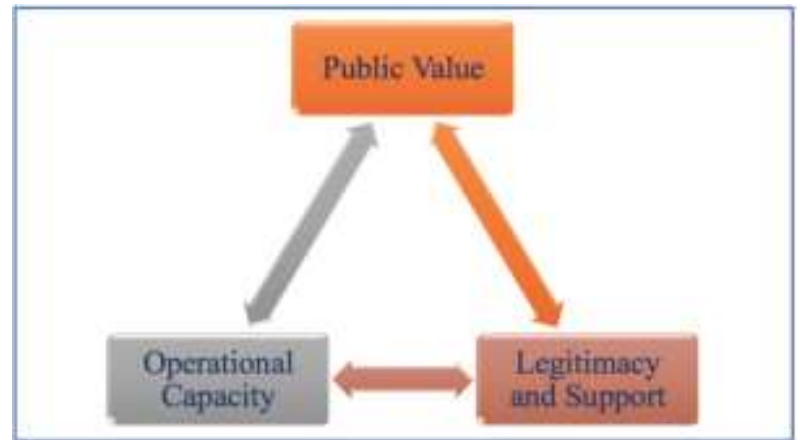

Figure 2. Strategic Triangle for the Public Sector by Moore

\section{Public Value to be Created}

According to Moore, every public organization should have an objective it wants to achieve. The civil service training management, for example, has the aim to increase value and enhance public servants' capacity.

\section{Source of Legitimacy}

This strategy focuses on the organization's capability to gain support from outside the organization, such as from citizens, members of house representatives, political actors, and media. These groups considered as the 'authorizing environment' (Moore, 2000).

\section{Operational Capacity to Deliver Public Value}

Functional capacity provided from within organizations. For example, staff, experienced leaders, budget, and organizational structure. This strategy requires an organization to have 'sufficient know-how' to achieve its desired goals.

\subsection{The Critics}

The three calculations discussed above are elements that organizations should have to create value. Having these three critical factors in organizations, however, does not necessarily lead the organizations to achieve their desired results. The result depends on whether an organization manages the strategy efficiently and effectively. 
O'Flynn (2013) and Katsonis (2018) argue that the element of capacity authorizing environment, including staff, leaders, budget, organization structure, or political leaders, could be a dichotomy in an organization. Based on their opinion, these elements can be enablers as well as barriers in delivering public value, depending on the management efficacy in the organization. For example, people (including leaders and staff) are the capacity in an organization that enables coordination by working together across 'hard and soft structures'; however, they can be barriers to cross these structures without the appropriate skills and competencies (O’Flynn, 2013; O'Leary et al., 2012; Williams, 2002). Another example is political leaders as powerful actors that lend support to organizations and empower others to collaborate (O'Flynn, 2013; Purdy, 2012); but also, can be 'significant barriers to the ability to operationalize' collaboration to achieve the desired outcomes (O'Flynn, 2013; Parston \& Timmins, 1998). Thus, Alford and O'Flynn (2009) suggest that the organization needs to develop a performance network to complement the strategic elements to create public value.

\section{Barriers in Training Management Efficacy}

Some training institutions also suffer ineffectiveness in management. Research shows that public sectors, particularly in developing countries, seek to boost their organization with capacity development programs, but find it challenging to produce qualified civil servants (JICA, 2014). Many developing countries have been criticized as they have advanced training systems but have not been meant that civil servants contribute significantly to their government (Tessema et al., 2007). Over the past three decades, despite the rapid changes in public administration, which was followed by the proliferation of management training, there has been a decrease in the managerial capability of public service (Reilly, 1987). For example, the World Development Report 1983 showed that around 66 percent of countries that we're borrowing from the World Bank to conduct capacity development programs, still experiencing 'acute shortage of high level technical and managerial skills' (Ozgediz, 1983). Capacity development is one of the civil service reform methods which is assessed to have been 'relatively unsuccessful compared to public financial reform' (Repucci, 2014). It can be seen that the developing countries had assumed training as a panacea to cure public administration problems and management in developing countries; while, it is not (Turner, 1989).

However, Turner (1989) has argued that training should not be blamed for its incapability to provide a significant contribution to management efficacy. There may be other reasons why training is having a small impact on civil service management. First, ineffective training might occur due to the resistance from the senior level of control to change their old ways (Reilly, 1987). The management level might encourage their subordinates to take training, but also make sure that training does not 'disturb their status quo' (Reilly, 1987). Secondly, Kubr and Prokopenko (1989) argue that many factors can simultaneously determine staff performance in public organizations, and not just training - for instance, lack of motivation, unclear job definition, failing to delegate, and low managerial authority.

\subsection{Supplementary Strategy for Management Efficacy}

Training programs in developing countries, therefore, could be perceived as a tool to improve the quality of personnel and managers, but 'should not be perceived as panacea' for all public administration problems (Kerrigan \& Luke, 1987). Therefore, instead of condemning the training program as the source of public management inefficacy, researchers suggest to make reforms to make a more efficient and effective training management for civil servants (Kerrigan \& Luke, 1987; Kubr \& Prokopenko, 1989; Lynton \& Pareek, 2011; Thomas \& Mellon, 1995; Wanassinghe, 1988). The researchers suggest ten critical factors affecting civil service training management. For each of the points, the 
following section will review the factor, discuss how it operates in Singapore, and why using Singapore as an illustration.

\section{The presence of a central coordinating agency}

A coordinating agency is a unit in government that coordinates activities between civil service organizations and the universities or colleges where training occurs (Tessema et al., 2007). The role of this coordinating agency is not to dictate; instead, it organizes, develops training programs, and facilitates coordination amongst stakeholders. Another task carried out by the coordinating unit is monitoring and evaluation of training-related activities. In performing assessments, the organization should be supported by stakeholders and external agencies or third parties. As the Singapore civil service training department is a unit under the Prime Minister, so, the organization plays a role as a coordinating agency between the Prime Minister and third parties. In other words, the central coordinating agency facilitates communication between policymakers and administrators or policy executors.

\section{The presence of written and operational civil service training policies}

Another critical factor in determining training management effectiveness is the presence of national training policies. Kerrigan and Luke (1987) argue that managing talent in developing countries could be challenging because of the absence of national training policies. The lack of training policies could make training as a mere activity while it is supposed to be an investment for organizations. The national training policies guidelines might include training-needs assessment, selection of training participant procedures, internal and external coordination mechanisms, and monitoring and evaluation procedures (Tessema et al., 2007). Training needs assessment is supposed to reflect the human capital development plan in the country (Kerrigan \& Luke, 1987). The government should consider linking training programs with career development (Paul, 1983; Edmunds, 1984). For example, more complex problems to handle after attending training might become a reason for the organization to promote its employees. Not only guiding the organization and its stakeholders, but the procedures are also essential to ensure and maintain organizational compliance with government regulation and plans.

\section{The linkage of training to research and consultancy}

The presence of specialist training consultants in civil service training management could assist in developing training programs. Training consultants could be hired from third parties; but, Tessema et al. (2007) suggest the civil service institution to have a consultancy with the college or universities where the government conducts training programs, for several reasons. First, the universities do research and consultancy as an integrated process and become part of the activities in the university organizations. Accordingly, a training consultant from the university milieu will bring expertise that comes from their research activity. Secondly, the universities are one of the training institutions' stakeholders who have a direct relationship with participants, so the universities could identify the participants' needs and help them improve the training programs. Subsequently, according to Tessema et al. (2007), research and consultancy provided by the faculty member could help the training management to improve performance. Therefore, consultancy from the universities benefits the organization with the updated information gained from research and promotes training efficacy.

\section{The presence of motivated, qualified, and experienced trainers}

Experienced and competent trainers are regarded as a vital capacity the organization should have to ensure the quality of training. Training institutions in Singapore have engaged qualified, experienced, and highly motivated educators to perform practical training (Tessema et al., 2007). The organization is also supporting the trainers 
or university members to attend a seminar, provide consultancy, and conduct research regarding issues in government or public organizations. The encouragement from the institution for trainers to do those activities could increase their knowledge and understanding regarding federal agencies (Kerrigan \& Luke, 1987; Yolsal et al., 2003). In turn, they could improve their qualifications and give them invaluable professional experience. Not only enhance the trainers' knowledge, providing opportunities for trainers to attend training would also motivate them to perform better (Tessema et al., 2007).

Kerrigan and Luke (1987), in line with other researchers, suggest for developing countries to provide training of trainers (TOT) that has been perceived as 'longer-term capacity-building strategy.' TOT will be best by partnering with overseas training institutions or world organizations such as the World Bank or foreign universities.

Another strategy worth exploring from the Singapore training departments is attracting high-qualified trainers with high salaries and providing fringe benefits that make the public sector more competitive with the private sector.

\section{The adequacy and reliability of financial resource for training}

An economic resource is one of the strategic elements for an organization to achieve its objective (Moore, 2000). It needs the government's commitment to making sustainable training organizations, not a mere training program but also training-related activities (Tessema et al., 2007). For instance, the Singapore training departments have adequate financial support from the government. The commitment from the government to provide financial support for the training institution has expedited the organization's plans. Developing countries, however, might have a financial barrier or financial inadequacy to support training programs for civil servants. Therefore, Kubr and Prokopenko (1989) suggest there are three primary financial sources that public service training could be provided: state budget, payments from training participants, and sponsorship from other organizations.

\section{The effectiveness of the leadership aspect of an institute}

Like in other organizations, the leader plays a vital role in managing civil service departments. To promote management efficacy in civil service training departments, the organization needs to appoint a leader who has qualifications, such as 'dynamic, resourceful, intellectually brilliant, progressively disposed and magnanimous' (Tessema et al., 2007). These qualifications are necessary to solve a complex problem in organizations. The leader should be able to articulate the objective of the organization, to focus on and prioritize issues in a critical situation.

Another consideration is, an effective leader has to have the ability to cross the departmental boundaries to facilitate better coordination with internal and external stakeholders. Tessema et al. (2007) found that the leader in the training management is a 'vital link' between training departments and colleges or universities, sponsorship agency, and communicator between government and other non-governmental agencies.

In terms of managing financial resources, one of the practical leadership abilities in managing financial support for training-related activities, training managers should be able to translate the organization's work plans and objectives into the budget. Kubr and Prokopenko (1989) argue that organizations, especially those being financed by the government, should consider cost-effectivity and increase internal efficiency as they spend public money. 


\section{The commitment of policymakers and senior civil servants to civil service training}

Encouragement from the government and training institution for officials to attend training should be in line with employees' motivation. In the Singapore model, the government has urged its policymakers and officials to attend training with target 100 hours per person per year, with a proportion of 40 percent for work-related courses and 60 percent on self-development training (Tessema et al., 2007). This policy is part of the national training policy to strengthen policymakers' and civil servants' skills, improve their practical ability, and for them to be up to date with the current issues. The training programs are also varied from formal (degree training) to informal training. Training programs are conducted in both domestic or local and overseas training institutions.

\section{The presence of local and international linkages}

A well-managed partnership and collaborations could drive innovations. Collaboration is the parties' willingness to enhance other's capacity (Himmelman, 2002). By partnering with well-known organizations, local or international organizations, the department could gather a wide range of relevant experience, especially in training development and management (Kerrigan \& Luke, 1987; Tessema et al., 2007). As collaboration could be a way to leverage resources and gain flexible solutions, the organization might work together with for-profit, not-for-profit, or voluntary organizations (Donahue \& Zeckhauser, 2011). The Singapore civil service training department, for example, is also linked to private organizations to enlighten the department with 'spark innovations.' With international organizations, the training department is related to the World Bank, Commonwealth Secretariat, Civil Service College (United Kingdom), and ASEAN. Given that collaboration with local organizations could produce innovative ideas (Hsieh et al., 2018) at relatively low-cost, the training department might collaborate with other ministries or local governments in conducting training, policymaking, and public management.

\section{The location of theo civil service training institute}

There are only a few training institutions for civil servants that are entirely independent; most of them are under government departments (Kerrigan \& Luke, 1987). Similar to the Singapore model, the structure distinguishes the relationship between the government, training department, and training institutions. The training departments have a direct relationship with the government, while on the other hand, training institutions have an indirect relationship with the government. Training departments are a department in the government that manage training programs and has a role as a training coordinator. University or College, on the other hand, is where the department sends the training participants to attend training, separated from the government structure. The Singapore training departments distribute the state budget for training programs held in training institutions. So, in terms of location, the training departments are located apart from the colleges or universities. Kerrigan and Luke (1987) found that conducting training in universities (or separating training locations with a department of government) could have positive aspects such as provide participants with library facilities and 'atmosphere' to learn and research.

\section{The continuity of monitoring and evaluation of training programs}

Monitoring and assessments are measurement approaches in performance management intended to achieve better training quality, management, facilities, and to reaffirm vision, mission, and the desired result (Kerrigan \& Luke, 1987). Conducting monitoring and evaluation of the training program could facilitate participants to provide feedback that can be used as evidence for the training department to improve the training management and programs. To those training institutions that cooperate with other 
institutions to hold training, evaluation could be a way to improve their training facilities (Tessema et al., 2007). Therefore, assessment is a powerful approach to measure achievement of the training objectives as one of the indicators for training management effectiveness.

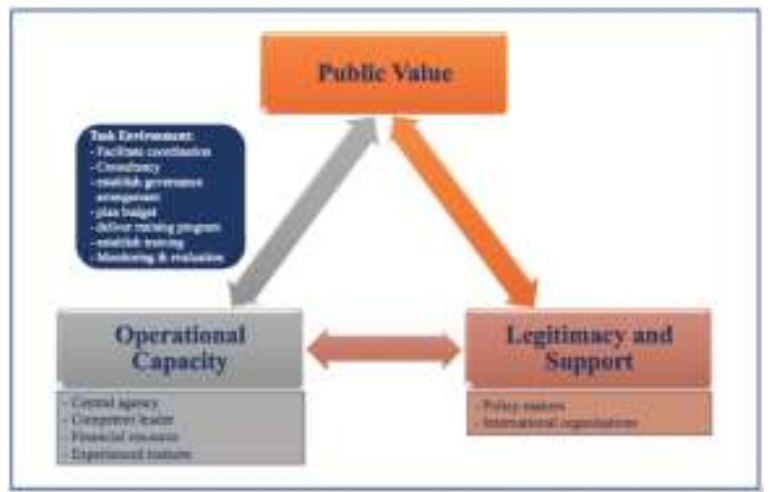

Figure 3. Mapping the Strategic Triangle for Training Management

Source: Adapted from Moore (2000) and Katsonis (2018)

In summary, the strategy from Moore and ten factors suggested by Tessema and colleagues are interrelated elements to optimize value in the civil service training management. The strategic triangle is a baseline for the organization to have, and the ten factors are the suggested directions for the institutions to perform most effectively and efficiently. In Katsonis (2018), the activities are done by the organization's capacity regarded as 'task environment' that links between public value and operational capacity. 'Task environment' can be a complement strategy and to deal with the barriers to achieving the desired results (Alford \& O'Flynn, 2009). The whole policy can be formulated as follows:

\section{Training Departments for Civil Servants with Planning Roles in Indonesia}

Training for civil service in Indonesia is classified into three categories: leadership training or structural, functional training, and technical training (Turner et al., 2009). This arrangement is determined in the Government Regulation Number 101 of 2000 the Implementation of the Certified Specialty-based Education and Training. Tjiptoherijanto (2012) defines the training categories as follows:

a. Leadership training designed for those who have just been promoted or holding managerial positions.

b. Functional training is arranged to improve civil servants' knowledge, general competence, and specific skills. The technical position consists of, e.g., planners, auditors, lawyers, teachers, who are categorized based on their competencies.

c. Technical training is arranged to improve skills related to the civil servants' positions.

While the National Institute of Public Administration organizes most of the leadership and technical training, functional training, particularly for those who have planning roles, is handled by the Centre for Planners Development Education and Training (CPDET).

\subsection{Background of CPDET: The History}


The CPDET is an Echelon II unit under the Ministry of National Development Planning, Republic of Indonesia (BAPPENAS). The organization was formed in 1984, named Overseas Training Office (OTO), by the Head of BAPPENAS. Since then, the nomenclature has changed several times, according to the vision at the time for the department (Figure 4).

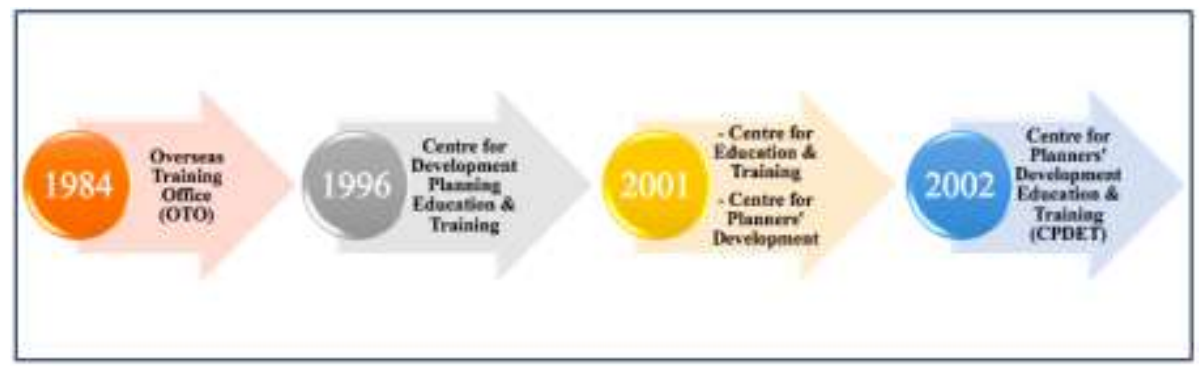

Figure 4. The History of the CPDET

Source: adapted from the CPDET website

OTO (1984-1996) was a part of the Bureau of Education and Training Administration (BETA) in BAPPENAS. The first role of the OTO (1984-1996) was to manage international grants to organize overseas degree training (postgraduate and doctoral degree) for civil servants' capacity development.

Based on the OTO accomplishment in managing international grants, the government decided to entrust the division with higher responsibility. In 1996, the division was merged with the BETA and named as the Centre for Development Planning Education and Training (CPDET). The organization developed the training program with a broader scope:

1. Deployed the scholars to domestic and overseas universities

2. Provided a standardized selection tool for prospective students

3. Conducted pre-departure training (English, Japanese, French, and Dutch)

4. Designed curricula for short term training or non-degree training

5. Designed budget for training

In 2001, the Minister of BAPPENAS decided to separate the organization into two divisions: the Centre for Education and Training and the Centre for Planners' Development (based on the Ministerial Decree No. KEP.009/Ka/01/2001). But considering that the roles of the divisions were interrelated, in 2002, the Minister merged the divisions as the CPDET (Ministerial Decree No. 50/Ka/03/2002). The Government of Indonesia appointed the CDPET to provide capacity development for the civil servants who have planning roles in central and regional governments.

\subsection{Role and Functions}

The vision of the CPDET is to facilitate and foster the functional planners through capacity development programs undertaken by civil servants in central and regional government offices, governed in the Regulation of the Minister of BAPPENAS No.4 of 2016 on the Structure and Governance of the BAPPENAS. Improving planners' capacity to contribute to better planning becomes crucial to compensate for the disparity of qualified planners in regional government. This role implemented by conducting training programs, degree and non-degree, formal and informal, particularly national development planning programs, as follows*:

1. To carry out education and training of development planning

2. To foster the functional planning civil servants' career development in central and local government 
3. To promote government apparatus trainers' career development in the Ministry of National Development Planning;

4. To formulate and determine policies on planners' development, education, and training

5. To develop training programs on development planning

6. To plan and develop curricula for training and learning development planning

7. To coordinate preparation and carry out training programs

8. To carry out control and evaluate the implementation of the training programs

9. To carry out accreditation for planning civil servants

10. To provide information regarding training programs held by the CPDET

11. To facilitate and coordinate the planner officials and government apparatus trainers' activities such as seminar and meeting

*Source: CPDET website (http://pusbindiklatren.bappenas.go.id/tugas-dan-fungsi.html)

The organization has three values which summarise the culture and the way the organization performs:

The first is an improvement (aimed to improve planning civil servants' quality), Second is Credible (the organization supported with competent staff that makes it more reliable). The third is Qualified (the organization is more quality-oriented rather than quantity oriented).

\subsection{Training Programs}

To meet the national planning needs, BAPPENAS has estimated that there has been an increase in the requirement for planners in central and local government offices. The estimation of the domestic demand is 2,300 planners for the central government and 39,200 for regional or local government (CPDET, 2013). Evidence from the Indonesian Bureau of Statistics (BPS) shows that a more significant number of planners work in central than the regional government and that their quality is higher. In terms of quantity, the percentage composition between civil servants in central and local government is respectively 20 and 80 (BPS, 2017). Out of the professional officials (in central and local), 26 percent are working for the central government (BPS, 2017), which is supposed to be 20 percent. So, there is a 6 percent gap, meaning the central government accounts for a 6 percent larger share than intended.

In response to the planning needs, the CPDET is a carrying-out degree and nondegree training programs held in domestic and overseas training institutes, as shown in Table 1.

Table 1. Training Programs

\begin{tabular}{|c|c|c|}
\hline & Degree Programs & Non-Degroe Frograms \\
\hline Domestic & $\begin{array}{l}\text { Mnster prognam } \\
\text { - Doctoral program }\end{array}$ & $\begin{array}{l}\text { Short term training program for planners } \\
\text { - Language programs (pre-departure training } \\
\text { \& English for Academic Purposes) }\end{array}$ \\
\hline Overseas & $\begin{array}{l}\text { - Master program } \\
\text { - Master Linkage program } \\
\text { - Doctoral program }\end{array}$ & $\begin{array}{l}\text { Sbort term training program } \\
\text { - Sbort term linkage program } \\
\text { - Staff enhancement } \\
\text { - Conference participation program }\end{array}$ \\
\hline
\end{tabular}

Not only to improve the civil servants' quality, but the training programs mentioned above also aim to increase the quantity of master and doctoral graduates in the government institutions. Data from BPS shows that there is only 2.3 percent of civil servants with master and doctoral degrees (2017). Moreover, out of the total number of civil servants (around 4.4 million), there are only 2,230 civil servants who have planning roles (JICA, 2013). It is estimated that the central and local governments need 41,500 
planners to meet the planning needs (BAPPENAS). Therefore, the necessity of the training programs is to 'correct the disparity in terms of number and quality' of the government's officials (CPDET, 2013).

\subsection{Working Mechanism}

Training programs conducted by the CPDET have national scope, which in turn, involves many organizations in the central and local areas. Moreover, the CPDET has to has coordinate with international agencies as they also contribute to financing the programs. The coordination amongst stakeholders is organized through a working mechanism as follows:

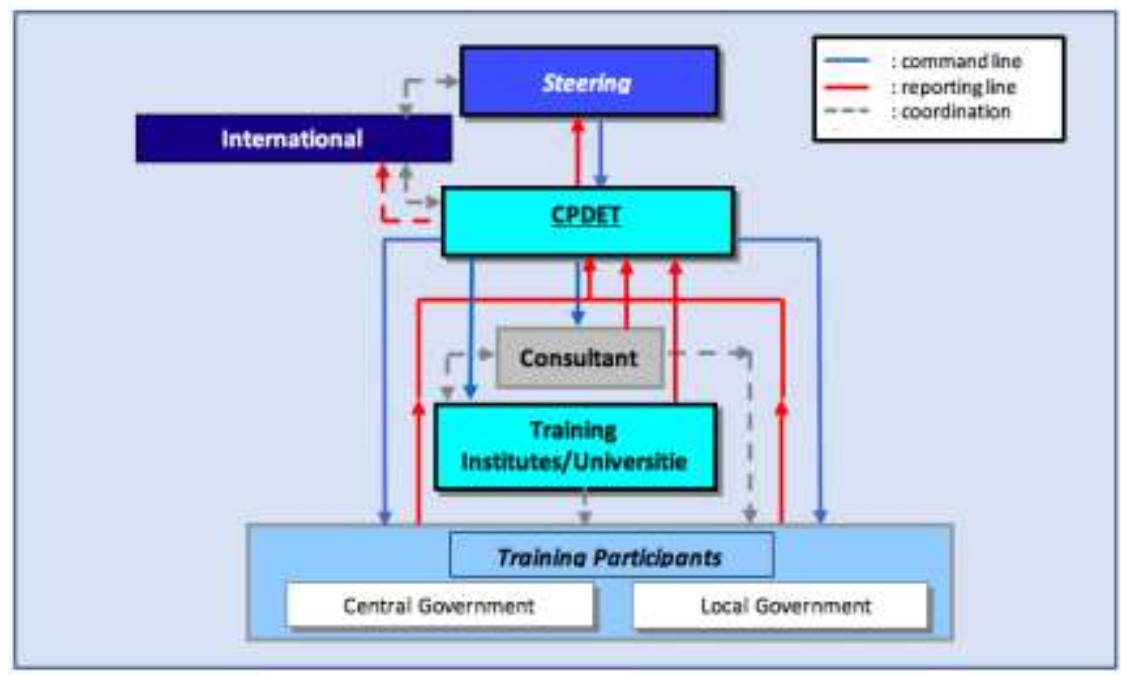

Figure 5. Working Mechanism

Source: Adapted from the CPDET Standard Operating Procedures

\subsection{Financial Resources}

Similar to in many other countries, a budget for improving capacity competes with other priorities such as health, security and defense, and culture. In Indonesia, although the government has nine priorities for development, education has been a focus for Jokowi as a way to empower the nation (Heriyanto, 2018). In 2019, the CPDET budget comprised 12 percent of the total from the ministry budget. The budget comes from two financial resources: the state budget (Government of Indonesia) and foreign loans, which used to finance training programs.

Table 2. Source of Fund

\begin{tabular}{|l|rr|rr|c|}
\hline \multicolumn{1}{|c|}{ Source of Funds } & \multicolumn{2}{c|}{ Ministry Budget } & & \multicolumn{1}{c|}{ CPDET } & $\%$ \\
\hline Government of Indonesia & $\$$ & 150.941 .716 & $\$$ & 9.352 .305 & $6 \%$ \\
\hline Foreign Loan & $\$$ & 16.759 .797 & $\$$ & 14.880 .064 & $89 \%$ \\
\hline Grants & $\$$ & 1.900 .350 & - & & $0 \%$ \\
\hline Direct Grants & $\$$ & 851.776 & - & & $0 \%$ \\
\hline Total & $\$$ & 170.453 .639 & $\$$ & 24.232 .369 & $14 \%$ \\
\hline
\end{tabular}

Source: CPDET budget

Based on the Law on National Education, No. 20/2003, and the Constitution Amendment, the government should allocate 20 percent of the total expenditure on education. Given this situation, the BAPPENAS formulates the budget that reflects the social arrangement and allocates most of the funding to capacity enhancement. 


\subsection{The CPDET and Decentralisation}

A broader responsibility was entrusted to the CPDET when Indonesia was implementing bureaucratic reform in 1998. The bureaucratic reform had changed the hierarchical relationship between central and local government. This massive change is regulated by the Fiscal Decentralisation Law No. 33/2004 and the Regional Governance Law No.32/2004, which imposed on local government responsibility for their jurisdiction, including planning and financing for mission in delivering public value. In this process, human resources are one of the crucial capacities required for the implementation of decentralization. In line with the schedule, the CPDET has been responsible for improving planner civil servants' capacity in the central and local governments.

After a decade of implementation, however, human resource management, although regarded as one of the crucial aspects in the decentralization, continues to receive less attention (Turner et al., 2009). The lack of skillful civil servants could hinder the government in implementing decentralization. Then in 2011, another agenda called 'reform the reformer' was performed by the Ministry of Empowerment of State Apparatus and Bureaucracy Reform (KemenPANRB) to support public administration reform (DFAT, 2012; KemenPANRB, 2012). One of the institutions appointed by the government to support this plan was BAPPENAS. The government delegates the institution to coordinate the capacity development program, namely the Scholarship Program for Strengthening the Reforming Institutions/SPIRIT. After that, the mission is delegated to the CPDET as a training department in the organization.

\section{Evaluating the '10 Critical Factors' in The Training Institution in Indonesia}

Key findings from the evaluation of the ten critical factors in the CPDET

\section{The presence of the central coordinating agency}

The CPDET, which is pivotal for planners' capacity development, has a role as a project implementing unit (PIU) and project coordinating unit (PCU) in charge of the whole program. As a PIU, the CPDET formulates training policy or policy guidelines regarding the implementation of capacity development programs. In formulating policies, the CPDET coordinates with stakeholders to get their advice and recommendations. As well, the CPDET encourages every government institution to have a human capital development plan (HCDP) as the fundamental or basis for sending their employee to a training program. Here, the role of the CPDET is to provide consultancy to these institutions in preparing the capacity development document.

As a PCU, the CPDET also coordinates stakeholders involved in implementing the programs, such as financial institutions, affiliate Universities, lecturers, training providers, consultants, and participants. Through a regular meeting with the stakeholders, the CPDET updates them with training policies and vice-versa, they will provide information regarding program implementation. The findings from the conference will report back to the Minister and lender institutions (please see Working Mechanism in Figure 5).

\section{The presence of written and operational civil service training policies}

There are two primary training policies in the CPDET:

\section{a. The HCDP}

The CPDET has used the HCDP as a guideline in developing training programs and assessing the training needs. The HCDP is regarded as a procedure to 'turn' human resources into human capital. The CDPET has been encouraging every institution to have this document since the beginning of 'reform the reformer agenda.' Now, there are 11 ministries in the central government and one regional government 
that have the HCDP documents, while some provincial governments are still formulating the report.

The HCDP determines the number of officials, required competencies, and training needs of an institution. By considering this document, the training programs could be matched with the skills needed by an institution. The HCDP does not only guide the design of training but is also a basis for the institution to undertake budget preparation and training demands from central and local governments.

Another function of the document is to guide the re-entry program. Re-entry is participants returning to institutions after attending longer-term training, usually a degree program. The lender, such as JICA, usually obliges the CPDET to encourage the participant's institution to place them in a planning-related unit or position upon the completion of the study program. This obligation is one of the effectiveness indicators of a training program (CPDET, 2013). The HCDP provides a guarantee to the participants to have a position relevant to their field of study; in other words, 'the right man in the right place.'

\section{b. Policy on Selection Criteria}

Described in the previous Chapter, a more significant proportion of planners work in central than local has led to a disparity. In response to the discrepancy of civil servants between central and local government, the CPDET formulates a selection policy that has different selection requirements for candidates from central government, local government in Java Island, and outside Java (Table 3). The target for participants is 20 percent from the central government, and 80 percent from the local governments. Thus, the participants from the local government are supposed to get a higher opportunity to be selected. Figure 6 illustrates the selection share between participants from central and local government, as a result of this policy.

Table 3. Selection Criteria

\begin{tabular}{|c|c|c|c|c|c|c|c|}
\hline \multirow{3}{*}{$\begin{array}{l}\text { Academic } \\
\text { Criteria }\end{array}$} & \multicolumn{5}{|c|}{ DetreeProeram } & \multicolumn{2}{|c|}{ Non-Degree Program } \\
\hline & \multicolumn{2}{|c|}{ Domestic } & \multirow{2}{*}{$\begin{array}{l}\text { Overseas } \\
\text { Mater } \\
\text { Unkage }\end{array}$} & \multicolumn{2}{|c|}{ Overseas } & \multirow{2}{*}{$\begin{array}{c}\text { Dverseas } \\
\text { Acadernic Staff, } \\
\text { Staif } \\
\text { Enhanconent, } \\
\text { Conference }\end{array}$} & \multirow{2}{*}{$\begin{array}{c}\text { Overseas } 8 \\
\text { Domestic } \\
\text { Ailshort-2 } \\
\text { term: } \\
\text { training } \\
\text { prosrams. }\end{array}$} \\
\hline & Doctoral & Master & & Doctaral & Manter. & & \\
\hline 1. TPA test* & \multicolumn{7}{|c|}{ (minimum score) } \\
\hline $\begin{array}{l}\text { - Central } \\
\text { Gov. }\end{array}$ & 565 & 565 & 565 & 565 & 565 & $\begin{array}{c}\text { Proposal-based } \\
\text { selection }\end{array}$ & - \\
\hline $\begin{array}{l}\text { - Local } \\
\text { Govt. (lava } \\
\text { Island) }\end{array}$ & 525 & 525 & 525 & 525 & 525 & $\begin{array}{c}\text { Propasal-based } \\
\text { selection }\end{array}$ & - \\
\hline $\begin{array}{l}\text { - Local } \\
\text { Govt. } \\
\text { (outside } \\
\text { Jova /sland) }\end{array}$ & 500 & 500 & 500 & 500 & 500 & $\begin{array}{c}\text { Proposal based } \\
\text { selection }\end{array}$ & - \\
\hline 2. TOEF"* & 500 & 450 & 450 & 500 & 450 & 500 & 450 \\
\hline
\end{tabular}

Source: adapted from the Project Memorandum PHRD IV

*TPA, similar to Graduate Record Examination (GRE), is a standardized test as an academic requirement

contains verbal reasoning, quantitative, and critical thinking.

**TOEFL Test of English as a Foreign Language 


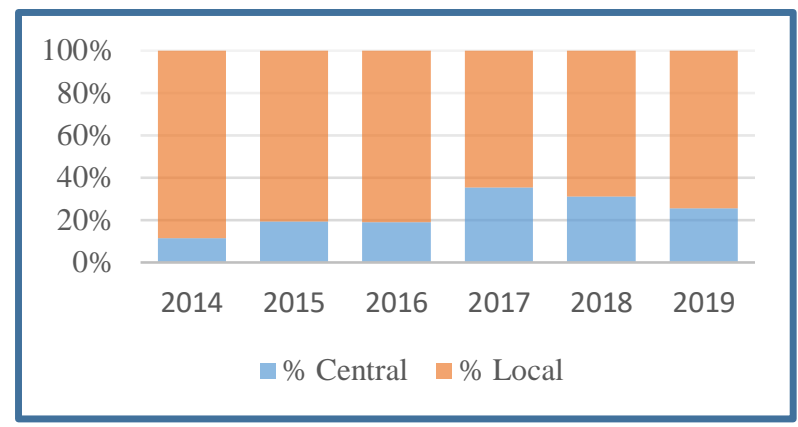

Figure 6. Selection Share between Central and Local

Source: Processed from the CPDET Number of Training Participants

\section{The linkage of training to research and consultancy}

In the Singapore model, research and consultancies are being executed by the lecturers or members of universities and colleges. Meanwhile, in the CPDET, research and consultancies activities are undertaken by experts from private consulting firms. The consultants are hired based on the demands of projects. For example, when the CPDET carried out two different programs, SPIRIT program and PHRD IV, each of the programs had various consultants. The consultants also research project implementation and progress quarterly. In doing research, the consultants permitted to contact the affiliate universities, the training providers, and training participants (on behalf of the CPDET), to gain data as a basis for their research and to prepare project reports.

Based on the Law on State Civil Administration No. 5/2014 and Government Regulation No. 53/2010 regarding the Discipline of Civil Servants, government officials are prohibited from holding positions such as lawyers, consultants, politicians, and working in a non-governmental organization. For example, a government official is not allowed to take part in political activities or work in a consultant agency (or individual consultant) - Code of conduct for civil servants to avoid conflict of interest and abuse of authority. Thus, as we can see in Figure 5, the universities and consultants are separate entities in the working mechanism.

However, the universities and training providers are usually invited to the regular coordination meeting to provide feedback and inputs regarding training implementations.

\section{The presence of motivated, qualified, and experienced trainers}

To ensure qualified trainers handle the training programs, the CPDET establishes agreements with the universities in Indonesia that are officially accredited by the Ministry of Research, Technology, and Higher Education of the Republic Indonesia (KemenRISTEK DIKTI). Only those universities accredited as Very Good (grade A), and Good (grade B) are eligible to be training institutes or counterpart universities of the CPDET (CPDET, 2013). The accreditation model in Indonesia based on the European Foundation of Quality Management and Malcolm Balridge's Model (Semuel \& Zulkarnain, 2012). Included in the measurements are research carried out by lecturers and the quality of publications. If the participants decide to study overseas, they are only permitted to choose the top 100 universities listed in the Times Higher Education and QS world university ranking.

The CPDET also believes that providing training of trainers could increase their motivation. Trainers or lecturers in the counterpart universities have opportunities to attend Staff Enhancement, Conference, Short Term Training, and Academic Staff program, provided by the CPDET. The target of these programs is around 20 people each year (CPDET, 2017). 


\section{The adequacy and reliability of financial resource for training}

The sources of finance come from the state budget and foreign loans. The CPDET benefits from loans from foreign financial institutions such as the World Bank/the International Bank for Reconstructions and Development (IBRD), JICA and Monbukagakusho (Japan), ADS/AAS (Australia), StuNed (Netherland), KOICA and KDI (South Korea), DAAD (German), CUD (Belgium), FCO (UK), USAID (USA), and CIDA (Canada). The state budget, however, is regarded as an additional fund that contributes share to overall funding. For instance, the Professional Human Resource Development Project IV (2013-2020), one of capacity development programs managed by the CPDET, is mostly supported by the JICA. Out of the total budget (AUD\$122.4million) of the PHRD IV program, funding from the Government of Indonesia is AUD\$23.2million, around 19 percent of the total budget (Project Memorandum PHRD IV 2013). Another project, the SPIRIT program, has 100 percent funding from the World Bank (AUD\$165.5million) (World Bank, BAPPENAS, and MOF, 2011).

The reliance of the organization on foreign loans is due to the government usually cutting the state budget in the middle budget year. In this situation, every ministry or institution is encouraged to reduce their organization's budget. Meanwhile, the budget needed for the degree program is supposed to be a limited budget; it means the budget cannot be cut during the study progress. Thus, the decision to use the loan to finance the capacity development programs reasonable as the loan is considered as a secured source of finance.

Not until 2019 did the CPDET initiate a scholarship program that is fully funded by the State Budget, namely the Premium Program. Around 75 civil servants are targeted to participate in this program. However, this program is a pilot project that cost around AUD2,9millions to finance 75 civil servants. The program is expected to continue if it is well-implemented, particularly in terms of budget sustainability.

\section{The effectiveness of the leadership aspect of an institute}

In the Indonesian government, the performance of Echelon I officials and Echelon II officials can be traced in the Key Performance Indicators. Echelon I officials hold top positions in a ministry such as a directorate general, while Echelon II is one level under Echelon I and includes places such as director or directorate-general secretary. Key Performance Indicators aimed to measure the effectiveness of the leader in managing the organizations. The efficiency measured through indicators adjusted to the mission of the organization. Four indicators reflect the leader's performance in the CPDET (Table 4). Table 4 shows the organization is achieving the key objectives that were generally higher than targeted.

Table 4. Key Performance Indicators 2018

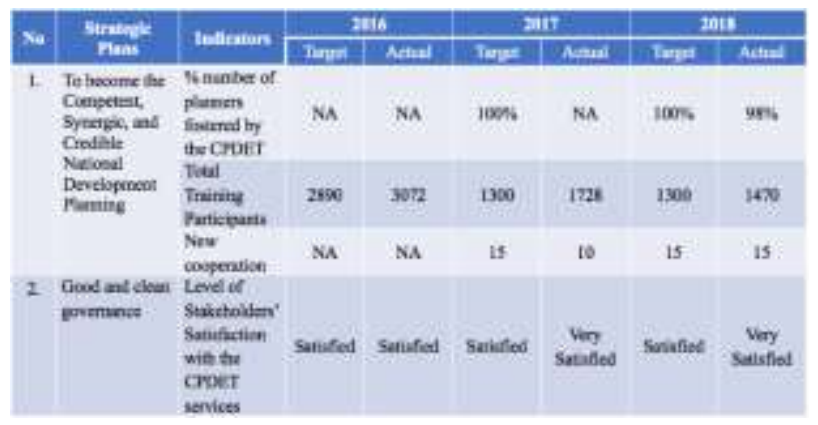

Source: KPI CPDET 2016-2018 
The performance of a leader also can be seen through their effectiveness, managing the budget, and distributing it according to the working plan (Raghunandan, Ramgulam, \& Raghunandan-Mohammed, 2012). The chart in Figure 7 illustrates the percentage of budget actualization from 2015 to 2019 . Overall, the budget compared to the actualization in the CPDET was relatively constant at around 90 percent each year. Amalgamating the two sets of information regarding KPI and Budget Actualisation, it can be seen that the leader of the CPDET could effectively and efficiently allocate resources to achieve the desired targets.

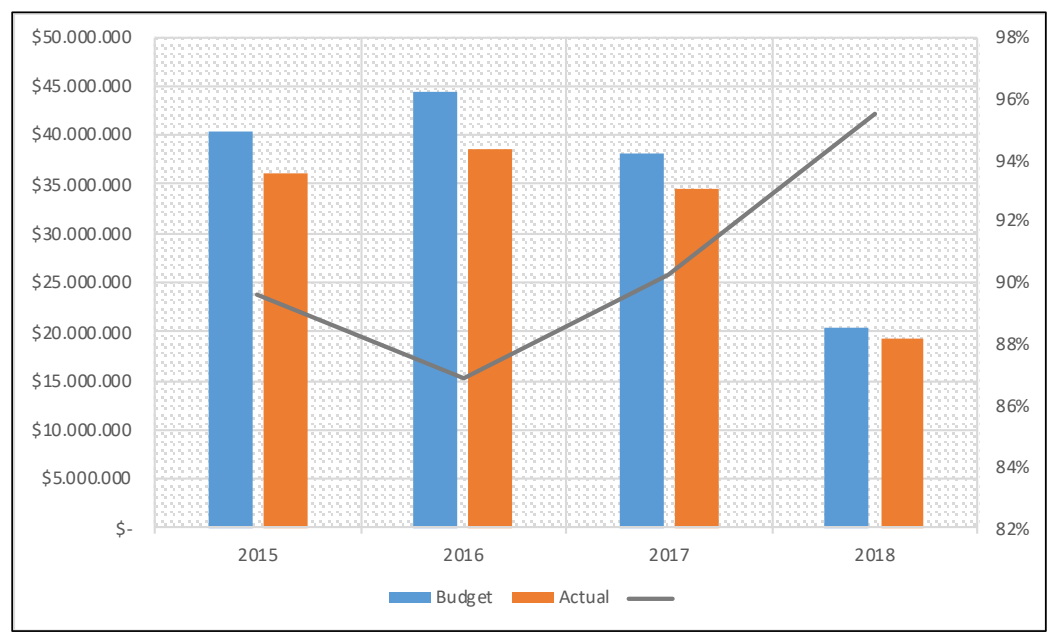

Figure 7. Budget Actualisation in CPDET

Source: Processed from the CPDET budget

\section{The commitment of policymakers and senior civil servants to training}

The determination of the politicians and senior civil servants to stimulate public service training proven by the continuity of capacity development programs and financial sustainability. The CPDET has been developed over the years, demonstrated from the improvement of its programs and the broader responsibility. The CPDET evolved from an organization that managed small grants for a few numbers of civil servants and now entrusted with a big responsibility to undertake national programs (see Figure 4). The continuity of the programs is impossible without a firm commitment from the leaders and the policymakers to allocate adequate budget, establish a partnership, and support that stimulates the organization's growth.

\section{The presence of local and international linkages}

As has been mentioned earlier in this chapter, the CPDET has strong partnerships with international organizations, e.g., World Bank, KOICA, JICA, which created since the beginning of the CPDET. The CPDET, moreover, has the objective of making a new agreement every year and puts this activity as one of the key indicators in achieving its strategic plan (Table 4). The cooperation legally enforced in the contract or agreement document. Not only linkages with financial institutions, but the CPDET also cooperates with training providers and universities at local and international levels. Within Indonesia, the CPDET has ties with more than 15 universities with excellent accreditation (e.g., Gadjah Mada University, University of Indonesia, Bandung Institute of Technology).

\section{The location of the civil service training institutes}

The CPDET cooperates with the counterpart universities to conduct training programs. For overseas programs under the SPIRIT project, the participants permitted to choose from the top 100 universities in the world (using Times Higher Education and QS 
rank). However, in the PHRD project, the choice is limited to Japanese universities as required by the lender, JICA. Also, for the linkages program, the participants will complete their first year in Indonesian universities, and the second year in the counterpart universities in Japan.

For domestic universities, the participants are also allowed to choose the counterpart universities, spread across Indonesian provinces and islands, such as in Sumatera Island (the University of Syiah Kuala, University of Brawijaya, University of Andalas), Java (the University of Indonesia, Bandung Institute of Technology) as seen in Table 5.

Table 5. Counterpart Universities in Indonesia

\begin{tabular}{|c|c|}
\hline Locition & Universilfes \\
\hline \multirow{3}{*}{ Sumatera } & University of Syiah Kuala \\
\hline & University of Andalas \\
\hline & University of Sriwijaya \\
\hline \multirow{7}{*}{ Java } & University of Indonesia \\
\hline & Bandung Institute of Technology \\
\hline & Padjadjaran University \\
\hline & University of Gadjah Mada \\
\hline & Bogor Institute of Agriculture \\
\hline & University of Diponegoro \\
\hline & University of Brawijaya \\
\hline \multirow{2}{*}{ Sulawesi } & University of Hasanuddin \\
\hline & University of Tadulako \\
\hline \multirow{2}{*}{ Papua } & University of Cenderawasih \\
\hline & State University of Papua \\
\hline
\end{tabular}

The distribution of training programs across these locations benefits the CPDET as well as the participants. First, the closer is the location to participants, the more likely it is that participants will be willing to attend the university. The decision to cooperate with two universities in Papua and Papua Barat, for example, is to encourage more participants from eastern Indonesia. The Focus Group Discussion (FGD) conducted by the CPDET in 2016 found that one of the reasons for the low participants from Papua and Papua Barat is due to the training locations. Training locations and universities located outside the island of New Guinea is considered a great distance to travel for the candidates from Papua and West Papua. Hearing from local governments in Papua and West Papua, the FDG recommended to the CPDET to cooperate with the University of Cenderawasih and the State University of Papua located in the Papua Island. After this cooperation commenced, there has been an increase in the number of participants from Papua and Papua Barat attending degree programs (Figure 8). 


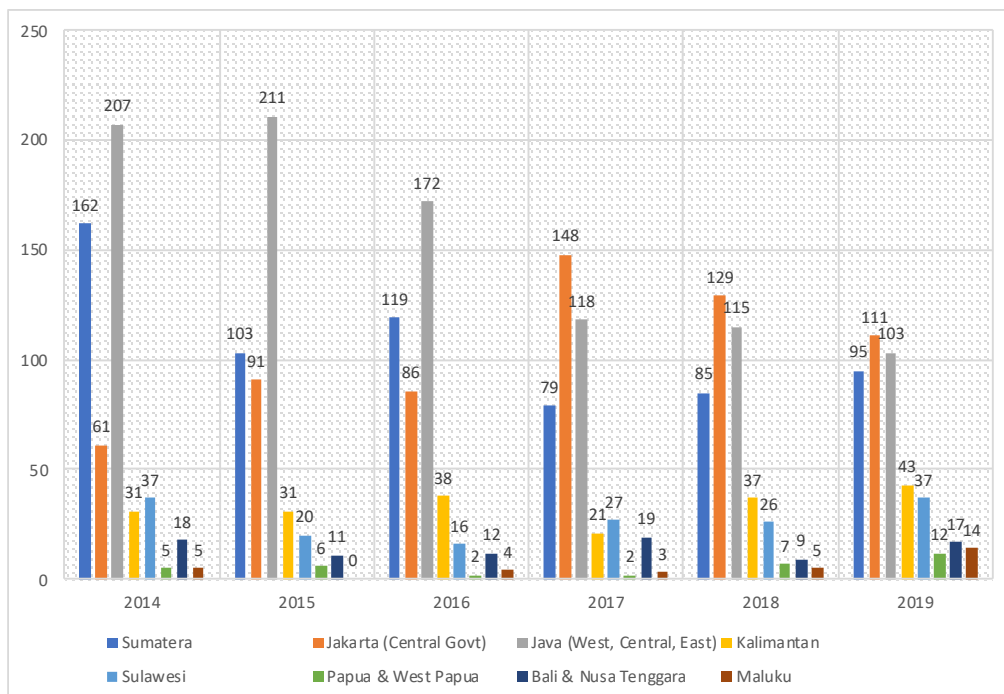

Figure 8. Number of Degree Training Participants Source: Processed from Numbers of Training Participants CPDET

\section{The continuity of monitoring and evaluation of training programs}

The CPDET performs monitoring and evaluation (ME) regularly reported to the Steering Committee and the lender as evidence in the policymaking and decision-making process. The report of ME provides recommendations intended to allow the program to have a better impact, effect, and assurance of the program sustainability. The lender, for example, JICA, will use the result of monitoring and evaluation of training programs as a basis or reference to continue the funding, for instance, the PHRD I to PHRD IV (PHRD I, 1990-1995; PHRD II 1995-2004; PHRD III 2004-2013; PHRD IV 2013-2020). The more significant contributions of the program to strengthening the institutions, the more likely the lender will continue the funding. There are six primary measurements for ME (Project Memorandum 2013):

Table 6. ME Measurement

\begin{tabular}{|c|c|}
\hline Insleatar & Deseriptian \\
\hline Budget epproporiotion & The CPDET secures the budget avallablity \\
\hline Target participants & Particapants are dvil servants who have planning rules \\
\hline Seiection methods of porticiponts & $\begin{array}{l}\text { Participants are } 20 \text { por cent from Central Goverwment } \\
\text { and } 80 \text { per cent from local govemment. }\end{array}$ \\
\hline Arces of study & $\begin{array}{l}\text { In selecting a program study, a participant murt refer } \\
\text { the three pillars of an area study: Economic Fannire. } \\
\text { Spatial Plannine-and Social Plannine. }\end{array}$ \\
\hline Aetumees cureer development & $\begin{array}{l}\text { Placine the returnees in a plannirz-related unit or } \\
\text { position upon the completion of the stuty program. }\end{array}$ \\
\hline
\end{tabular}

\section{Analysis of The Key Findings}

Based on the report in Chapter 4, it concluded that the ten critical factors affecting training management institutions implemented in the CPDET. The CPDET training management model has strategic elements similar to the Singapore model, which may lead the training management to achieve the key objectives: strengthening the planners' capacity and good governance. However, there are two elements in the strategy which differ significantly between Singapore and the CPDET in managing training institutions. As shown in the strategic triangle (Figure 9), the first difference is how the organizations 
obtain financial resources and, secondly, how policymakers are committed to supporting the capacity development programs.

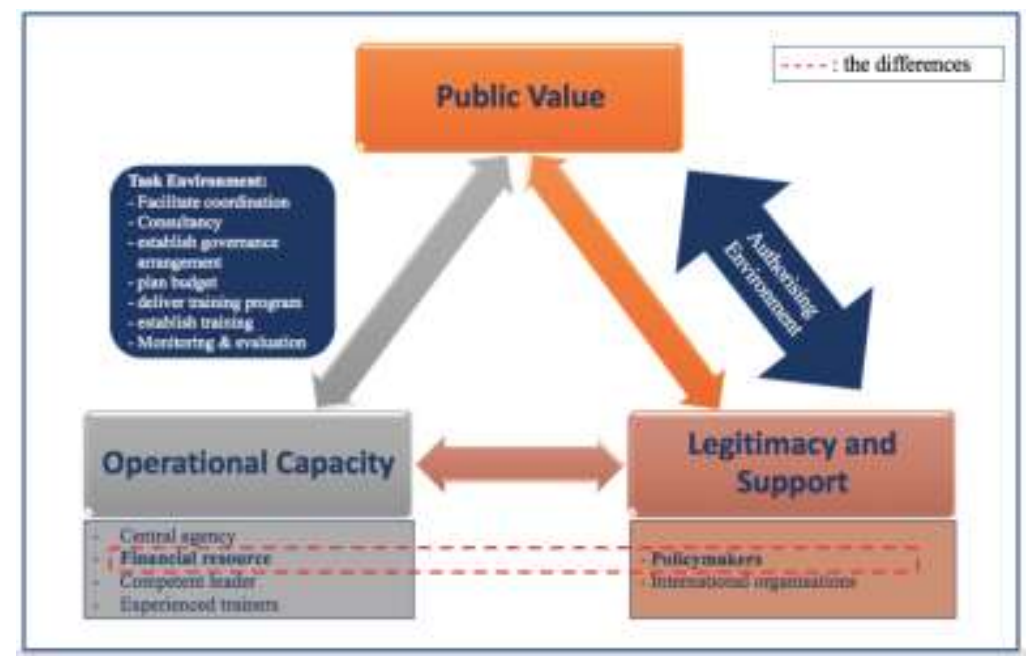

Figure 9. Mapping the Differences between CPDET and Singaporean

Training Institution

Source: Adapted from Moore (1995); Alford \& O’Flynn (2009); Katsonis (2018)

\subsection{Mapping the Main Differences}

\section{Financial Resource}

A significant difference between the Singapore model and Indonesian model is in the way the two organizations secure their sources of finance. In the Singapore model, the funding comes from five sources: revenue from training, income from consultancy, income from research, government grants, and other income (Low, 2016). On average, the revenue generated from profitable activities contributes more than 80 percent of the total financial resources required (Low, 2016). The resilience of the training institution in Singapore during critical economic times, such as the Global Financial Crisis (2008) and Singapore recession (2003), has proved that the institution has a robust and steady budget. Indeed, during these times, the training institution did not reduce its target number of participants. Moreover, the government's commitment to training its service officers and firm support from policymakers results in an excellent financial situation (Quah, 1995).

In Indonesia, on the other hand, a working unit with a regular financial management pattern, such as the CPDET, is prohibited from generating its revenue. It is a 'spending unit' that gains budget allocations from the Government (including loans or grants) and spends those allocated funds. Another example of a working unit in the same financial position is the Directorate General of Taxes (DGT). Even though the group is collecting taxes from the public, this revenue directed to the Government (Law No. 1/2004 article 16), it is clear that the working units such as the CPDET and the DGT are not allowed to earn money; and indeed, it leads to the difference with the Singapore model where the groups with responsibility for training are allowed to make profits to retain for their use.

Another financial issue in Indonesia is the cut in the State Budget that occurs during the middle of the budget year. Also, sometimes the government has to reallocate 
available funds to a more prioritized program. The budget cut can have devastating implications for the CPDET if the training program fully funded from the state budget. For instance, a program that is still in progress will lose its financial backing, which may, in turn, impact on a participant's living allowance and study progress. This is the reason behind the decision to use foreign loans rather than the State Budget as the primary source of finance for the programs.

Although the CPDET is prohibited from generating revenue from the public, however, it does not mean that the organization is not supported adequately financially. The organization has a tight budget from loans and partially from the Government. Hence, policymakers encourage the CPDET to propose new funding from lenders, and indeed, the investment will sustain the program.

Overall, depending on the state budget to finance training programs can be difficult for several reasons: the state budget is limited and could be cut for efficiency savings. However, it can be argued that depending on foreign loans may burden the country due to higher levels of international debts. Hence, finding other options for financial sources should become a consideration.

If we look more closely at the pattern of financial management of the public service, there are working units that are allowed to gain revenue by producing goods or servicesthese units based on the Public Service Entity financial mechanism (BLU). Referring to the Government Regulation No. 23/2005, a BLU is established under a state ministry to undertake public service and gain revenue, but profit is not the primary objective. The BLU unit introduces financial management that is flexible under the public service framework to improve efficiency and productivity (Santi dan Rosita, 2009; Maharani dan Adi, 2013; Waluyo, 2014; Kasih, 2014; Rongiyati, 2016;).

Table 7. The Pattern of Financial Management of Public Service

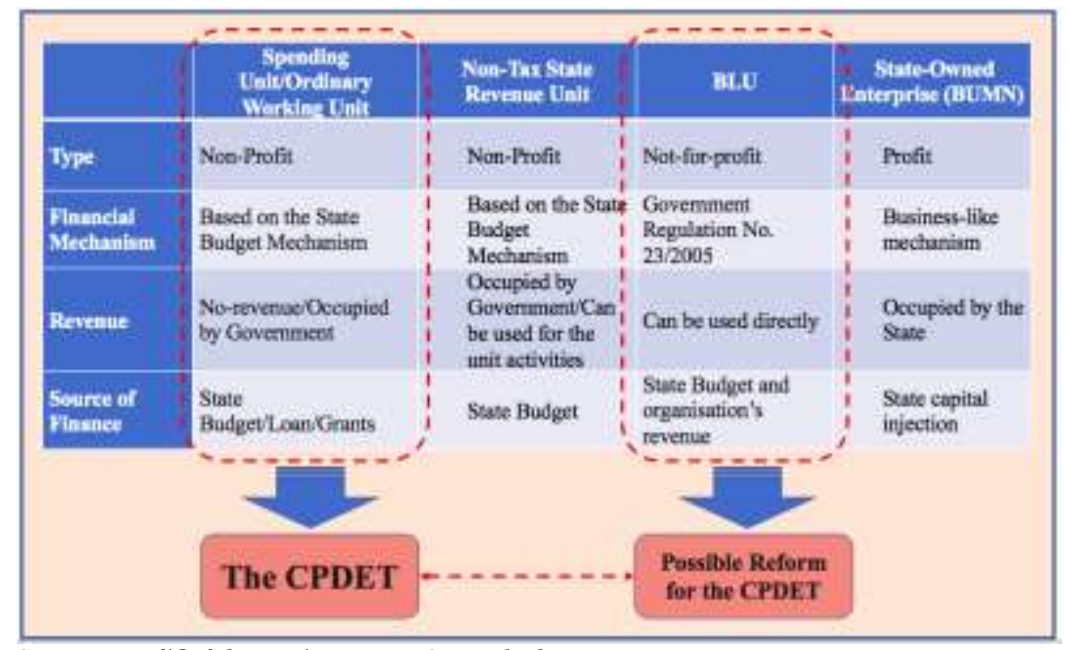

Source: Modified from Directorate General of Treasury MoF 2011

For that reason, a BLU can be an alternative way to organize a working unit in government, which is undertaking service functions (Kasih, 2014), such as the CPDET. In 2015, the head of CPDET considered to reform the CPDET into a BLU to promote finance flexibility; but, this not supported at the higher level of government for several reasons. Firstly, the training programs conducted by the CPDET are provided for planner civil servants only and are not open to the public. A planner civil servant, must become a civil servant and pass examinations before being promoted as a planner. Any training expenditures for planners will be financed by the government, as they will and are 
expected to contribute to the government's interests. Secondly, allowing CPDET to become a BLU would mean that BAPPENAS would lose one of its functions, as a 'thinktank' (see also Role and Function of BAPPENAS, 2019). To perform this function, BAPPENAS has a responsibility to 'strengthen planners' capacity at the central and regional level and engage in participatory planning through cooperation with universities' - it is CPDET which has executed these roles (BAPPENAS, 2019). If the CPDET was to become an autonomous unit, this, in turn, will release the CPDET from BAPPENAS. The impact is, BAPPENAS as the state ministry of national planning, will lose its function and power to develop planners' capacity and foster their career development.

\section{Policymakers and Political Elites}

A comparison of the political-administration nexus between Singapore and Indonesia can illustrate using the Government Effectiveness Index (GEI) provided by the World Bank. GEI "captures the perceptions of the quality of public service and the degree of its independence from political pressure" (World Bank, nd). In 2017, the GEI placed Singapore in the highest rank (2.21 out of 2.5 points) and Indonesia in the 84th place (0.04 points). It implies that Singapore has the highest credibility in representing public visions and has the highest degree of independence from political pressure. On the other hand, the interdependence between public administration and the political environment in Indonesia still seems to have a scope for further improvement.

The political-administration nexus above mentioned is likely having a strong influence on budget appropriation and decision-making process for the CPDET. As described by Charbit and Vammale (2010), the government administration and political environment are two highly interdependent environments. Policymakers have a strong influence in making any changes in an organization (Bunse \& Fritz, 2012). For example, as mentioned above, the politicians have reliable power in determining the source of finance for the CPDET. The strong influence of the policymakers and political elites in Indonesia might lead to a challenge to the CPDET to reform from being an Ordinary Working Unit to become a unit that is less dependent on the foreign loan (BLU). Not only for the CPDET, but every substantial change in the government offices must be consulted on with and endorsed by the House of Representatives.

In summary, the CPDET can have a flexible financial stream, but for this to succeed, support from the policymakers and political elites would be needed.

\subsection{Can the CPDET Be as Effective as The Singapore Training Institution?}

Although the financial resource and political issues, the capacity development program conducted by the CPDET has made a significant contribution to strengthening the planning units in Indonesia (Jatileksono, 2015; Project Completion Report, 2016). The survey of alumni from the program conducted by Jatileksono (2015) shows that the training programs under CPDET management contribute positive impacts to participants in several ways:

\section{Strengthening the Institutions}

Most of the supervisors confirm that alumni contribute to increasing their institution's capacity in several ways, such as better planning and program implementation, better monitoring and evaluation, transferal of knowledge to officemates, promotion of innovation, reducing inefficiency in institutions, and providing better service quality.

\section{Increasing Private and Social Income of The Alumni}


The study conducted by Jatileksono (2015) shows that those who hold a master's or doctoral degree have a higher private income (accordingly with their promotion) and social rent (their willingness to do overtime work without being paid).

\section{A Vehicle for Promotion}

Based on the survey of alumni, 77.3 percent promoted after re-entry to their institution: 41 percent of them promoted less than a year after graduation; 28 percent within 1 to 2 years; 14 percent within 2 to 3 years; and less than 20 percent who promoted more than three years.

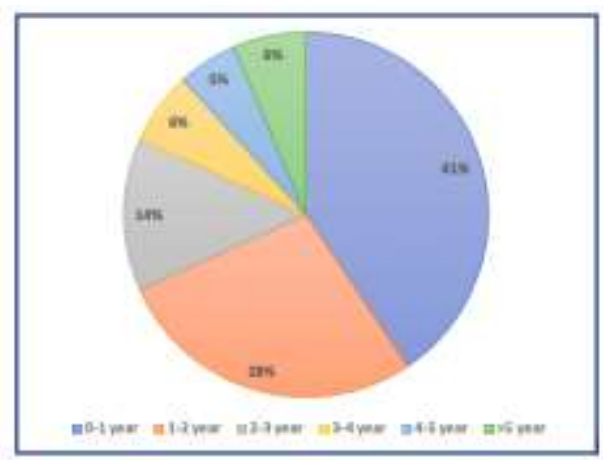

Figure 9. Distribution of Promoted Alumni after Graduation Source: Processed from Tracer Study Alumni data (Jatileksono, 2015)

Therefore, the CPDET training management model can be as effective as the Singapore model, although in different ways.

In summary, this research finds that nine out of the ten critical factors for better civil service training management in the Singapore model could be implemented in CPDET training management. Policymakers in Indonesia are committed to supporting the training institutions, although in a different way to in Singapore. Pollit (2003) adds that those who have power are supposed to steer and to facilitate success in the organization. It is possible to copy the Singapore model as a whole; however, the CPDET might find it challenging to persuade the key players of the authorizing environment to switch the source of finance to allow reform of the financial administration.

\section{Conclusion}

This thesis has undertaken a literature review, archival document evaluation, and empirical research to compare the effectiveness of training management in Singapore and the CPDET in Indonesia. The findings suggest that the factors that explain the success of training management in the Singapore model are relatively well-implemented in Indonesia. Also, other elements in the CPDET contribute to the effectiveness of training management. This study also finds that legitimacy - support from policymakers and political elites - is critical in determining operational capacity, such as sources of finance for the organization to be sustainable.

The study has limitations as it is using the 'lens' of a developed country to understand a government administration in a developing country, which might lead to bias. In the political context, the Singapore government has a political environment that relatively stable, while in Indonesia, it still needs to improve. Thus, applying the authorizing environment in Singapore to Indonesia could introduce some inappropriate generalizations as the political environment in both countries might differ. For that reason, this study added some complementary elements to evaluate. 
A particular strength of this study is that this thesis has considered factors in addition to the ten critical factors for management effectiveness in public organizations, such as value to be created, source of legitimacy and support, and operational capacity to deliver value; which are more general and applicable for either developed and developing countries. Also, the thesis has included quantitative-type research regarding alumni contributions to their organizations.

In conclusion, the findings from the study reflect the results from previous empirical studies regarding factors affecting training management efficacy. Effectiveness of a training organization is not merely about how the management manages its capacity, or how the leader persuades policymakers and political actors, but about how training can contribute to strengthening the participants' organization and provide private benefits to them. However, training management effectiveness may be measured differently between countries. Whether or not the ten factors can be implemented in a nation depends on the commitment of all stakeholders engaged in the training governance.

\section{Recommendations:}

1. BLU can be a solution for working units under public organizations, particularly those who have service functions like the CPDET. BLU could provide financial flexibility and promote good governance and create less dependence on political pressure. However, in the early implementation, financial contributions from the government are still likely to be necessary to provide a robust and steady budget.

2. There are some areas worthwhile to explore. Further research could combine the tenfactors affecting training management institutions, other factors that may affect training management, and also the evaluation of the training programs to measure the effectiveness of the training management. It would be possible to undertake an assessment of training programs using a comparison between training participants and a control group of non-participants (see Borland, Tseng, and Wilkins, 2004). The research suggested being conducted several years upon the training completion.

\section{References}

Alford, J., \& O'Flynn, J., 2009. Making sense of public value: Concepts, critiques, and emergent meanings. International Journal of Public Administration, 32(3-4), pp.171191.

Borland, J., Wilkins, R., \& Tseng, Y.P., 2005. Experimental and quasi-experimental methods of microeconomic program and policy evaluation. Melbourne Institute of Applied Economic and Social Research. Pp. 83-118.

Bunse, S., \& Fritz, V., 2012. Making public sector reforms work: Political and economic contexts, incentives, and strategies - the World Bank.

Center for Planners Development Education and Training, 2013. Project Memorandum. Jakarta.

Center for Planners Development Education and Training, 2017. Key Performance Indicator 2016.

Center for Planners Development Education and Training, 2018. Key Performance Indicator 2017.

Center for Planners Development Education and Training, 2019. Key Performance Indicator 2018.

Center for Planners Development Education and Training, 2019. Profile. http://pusbindiklatren.bappenas.go.id. 15 August 2019. 
Charbit, C., \& Vammalle, C., 2010. Modernizing government. Making reform happen lessons from OECD countries, pp. 209-237.

Department of Foreign Affairs and Trade, nd. Strengthening the Reform of the Reformers/Inspire Project through Programmatic Consolidation. Australia. https://dfat.gov.au/about-us/publications/Documents/indonesia-bureaucraticreform-concept-note.pdf. 1 September 2019.

Donahue, J.D., \& Zeckhauser, R.J., 2011. Collaborative governance: Private roles for public goals in turbulent times.

Edmunds, S.W., 1984. Strengthening administration of the development process. International Journal of Public Administration, 6(2), pp.217-243.

Heriyanto, D., 2018. Here are Jokowi-Ma'ruf's nine 'missions' for 2019's presidential poll. The Jakarta Post.

Heymann, P.B., 1987. The politics of public management. New Haven, CT: Yale University Press.

Himmelman, A.T., 2002. Collaboration for change (revised January 2002). Definitions, decision-making models, roles, and collaboration process guide. Minneapolis: Himmelman consulting.

Hsieh, W.L., Ganotakis, P., Kafouros, M., \& Wang, C., 2018. Foreign and domestic collaboration, product innovation novelty, and firm growth. Journal of Product Innovation Management, 35(4), pp.652-672.

Indonesian Bureau of Statistics, 2017. Number of Civil Servants 2013-2016. Indonesian Bureau of Statistics. Jakarta. https://www.bps.go.id/statictable/2015/09/08/1798/jumlah-pegawai-negeri-sipilmenurut-jenis-kepegawaian-dan-jenis-kelamin-desember-2013-dan-desember2016.html. 15 August 2019.

Japan International Cooperation Agency, 2014. Project memorandum on PHRD-IV between JICA and BAPPENAS. Jakarta, pp.1-16.

Jatileksono, T., 2015. Final Report: Tracer and Impact study of Professional Human Resource Development Project Phase-III-The Case Regular Program.

Kasih, D.P.D., 2014. The Existence of Public Service Entity 'Badan Layanan Umum'To Undertake Governmental Function. Kumpulan Jurnal Mahasiswa Fakultas Hukum, 1(1).

Katsonis, M., 2018. PADM90007 The World of Public Administration: Seminar 2 Day 1, PowerPoint slides, The University of Melbourne.

Kerrigan, J.E., \& Luke, J.S., 1987. Management training strategies for developing countries. Lynne Rienner Publisher.

Kubr, M., \& Prokopenko, J., 1989. Diagnosing management training and development needs: Concepts and techniques (No. 27). International Labour Organization.

Low, J., 2016. Milestone programs for the administrative service in the Singapore Public Service. Sharpening the Sword Of State, p.181.

Lynton, R.P., \& Pareek, U., 2011. Training for development. SAGE Publishing India.

Maharani, A. dan Adi, W., 2013. Analisis Kinerja Keuangan Sebelum dan Sesudah Penerapan Pola Pengelolaan Keuangan Badan Layanan Umum. Jurnal Pendidikan Ekonomi, 1(3).

Moore, M.H., 1995. Creating public value: Strategic management in government. Cambridge, MA: Harvard university press.

Moore, M.H., 2000. Managing for value: Organizational strategy in for-profit, nonprofit, and governmental organizations. Nonprofit and voluntary sector quarterly, 29(1), pp.183-204.

O’Flynn, J., 2013. Crossing boundaries: the fundamental questions in public management and policy. In Crossing Boundaries in Public Management and Policy (pp. 31-64). Routledge. 
O'Leary, R., Choi, Y. \& Gerard, C.M., 2012. The skillset of the successful collaborator. Public Administration Review, 72(s1), pp.S70-S83.

Ozgediz, S., \& Sachdeva, P., 1983. Managing the public service in developing countries. Washington, DC: World Bank.

Parston, G., \& Timmins, N., 1998. Joined-up management. Public Management Foundation, London.

Paul, S., 1983. Training for public administration and management in developing countries: $A$ review (Vol. 1). Washington, DC: World Bank.

Pollitt, C., 2003. Joined-up government: a survey. Political studies review, 1(1), pp.34-49.

Prahalad, C.K., \& Hamel, G., 1990. The core competence of the corporation. Harvard Business Review, 68(3). Pp.79-91

Purdy, J.M., 2012. A framework for assessing power in collaborative governance processes. Public Administration Review, 72(3), pp.409-417.

Quah, J.S., 1995. Sustaining quality in the Singapore civil service. Public Administration \& Development (1986-1998), 15(3), pp.335-343.

Raghunandan, M., Ramgulam, N., \& Raghunandan-Mohammed, K., 2012. Examining the behavioral aspects of budgeting with particular emphasis on public sector/service budgets. International Journal of Business and Social Science, 3(14).

Reilly, W., 1987. Management and training for development: the Hombe thesis. Public Administration and Development, 7(1), pp.25-42.

Repucci, S., 2014. Designing effective civil service reform lessons from past experience. Public Administration and Development, 34(3), pp.207-218.

Rongiyati, S., 2016. Analisis Yuridis Pengelolaan Keuangan Badan Layanan Umum Pada Instansi Pemerintah Penyelenggara Layanan Umum. Negara Hukum: Membangun Hukum untuk Keadilan dan Kesejahteraan, 2(1), pp.1-27.

Santi, E., dan Rosita, I., 2009. Implementasi dan kendala penerapan pengelolaan keuangan badan layanan umum (BLU). Jurnal Akuntansi \& Manajemen, 4(2), pp.41-54.

Semuel, H. dan Zulkarnain, J., 2012. Pengaruh sistem manajemen mutu ISO terhadap kinerja karyawan melalui budaya kualitas perusahaan (Studi kasus PT. Otsuka Indonesia Malang). Jurnal Manajemen dan Kewirausahaan, 13(2), pp.162-176.

Sumedi, P.A., 2008. Berbagai Modul Sistem Mutu Dan Penerapannya Dalam Dunia Pendidikan.

Tessema, M.T., Soeters, J.L., De Groot, G., \& Tesfaselassie, M.F., 2007. Managing civil service training institutions: what lessons can countries learn from Singapore? International Journal of Human Resources Development and Management, 7(3-4), pp.300-318.

The Global Economy, 2019. World Bank: Government Effectiveness Index. https://www.theglobaleconomy.com/rankings/wb_government_effectiveness/. 1 September 2019

Thomas, K., \& Mellon, T., 1995. Planning for training and development: A guide to analyzing. needs. Save the Children.

Tjiptoherijanto, P., 2012. Civil Service Reform in Indonesia: Culture and Institution Issues. Department of Economics, Faculty of Economics, University of Indonesia.

Turner, M.M., 1989. 'Training' revisited in Papua New Guinea. Public Administration and Development, 9(1), pp.17-28.

Turner, M., Imbaruddin, A., \& Sutiyono, W., 2009. Human resource management: the forgotten dimension of decentralization in Indonesia. Bulletin of Indonesian Economic Studies, 45(2), pp.231-249.

Waluyo, B., 2014. Analisis permasalahan pada implementasi pola pengelolaan keuangan Badan Layanan Umum. Jurnal Infoartha, 3, pp.27-38.

Wanasinghe, H.S., 1988. Management Development in Public Administration: The Experience of Sri Lanka. Indian Journal of Public Administration, 34(3), pp.790-797. 
Williams, P., 2002. The competent boundary spanner. Public administration, 80(1), pp.103124.

World Bank, The Ministry of National Development Planning, and The Ministry of Finance Republic Of Indonesia, 2013. Project Operation Manual SPIRIT. Jakarta.

Yolsal, N., Bulut, A., Karabey, S., Ortayli, N., Bahadir, G., \& Aydin, Z., 2003. Development of training of trainers' programs and evaluation of their effectiveness in Istanbul, Turkey. Medical teacher, 25(3), pp.319-324.

\section{Regulations}

Law on the Ordinance on Civil Service No.43/1999. (Indonesia)

Law on Education No.20/2003. (Indonesia)

Law on State Treasury No.1/2004. (Indonesia)

Law on Regional Governance No.32/2004. (Indonesia)

Law on Fiscal Decentralisation No.33/2004. (Indonesia)

Law on State Administration No.05/2014. (Indonesia)

The Government Regulation No. 101/2000. (Indonesia)

The Government Regulation No.53/2010. (Indonesia)

The Ministry of National Development Planning Decree No. KEP.009/Ka/01/2001. (Indonesia)

The Ministry of National Development Planning Decree No.50/Ka/03/2002. (Indonesia)

The Ministry of National Development Planning Regulation No.04/2016. (Indonesia) 